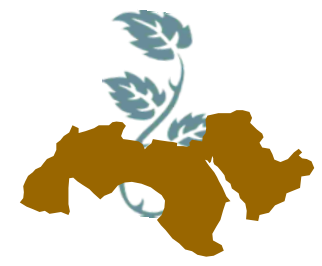

Arab Univ.

J. Agric. Sci., Ain Shams Univ., Cairo, 24(2), 581-591, 2016

\title{
RESPONSE OF POT MARIGOLD (Calendula officinalis $L$.) TO DIFFERENT APPLICATION METHODS AND CONCENTRATIONS OF SEAWEED EXTRACT
}

\author{
Tartil, M. Emam; A.M. Hosni; A.K. Ibrahim and M. Hewidy \\ Horticulture. Dept., Fac. Agric., Ain Shams Univ., Cairo, Egypt \\ ${ }^{*}$ Corresponding author, email: Tartil Emam@yahoo.com
}

Keywords: Pot marigold, Calendula officinalis, Seaweed extracts, Flowering, Vase life, Carotenoids, Nitrogen, Phosphorus, Postharvest life, Biostimulant

\section{ABSTRACT}

This research study was carried out in the open field during the two successive seasons of $2012 / 2013$ and $2013 / 2014$. The aim of this investigation was to study the response of pot marigold (Calendula officinalis L.) to different application methods and concentrations of seaweed extracts applied as a commercial compound. Seven treatments were initiated, i.e. three concentrations of seaweed extracts $(500,1000,1500)$ were used either as foliar spray or as soil drench in addition to the control treatment (tap water). Results indicated that foliar spray with $1500 \mathrm{ppm}$ of seaweed extract increased significantly plant height, number of flowers per plant and vase life in the two tested seasons. However, foliar spray with the lowest concentration of seaweed extract $(500 \mathrm{ppm})$ resulted in significant increments in flower stalk length, flower diameter and carbohydrates content. Moreover, the same concentration showed significant increases in total carotenoids, nitrogen, and phosphorus percentage when used as soil drench in the two tested seasons.

\section{INTRODUCTION}

Pot marigold (Calendula officinalis L.) is an herbaceous plant belongs to family Asteraceae. Pot marigold has been cultivated in Egypt for its importance as an ornamental, medicinal and deco- rative plant. In recent years a growing interest has been observed with natural biostimulanting substances. The groups of leading biological factors showing a favorable effect on many plants include seaweed extract. Liquid extracts obtained from seaweeds have recently gained importance as foliar spray or soil drench applications for many crops including various grasses, cereals, flowers and vegetable species(Norrie \& Keathley, 2006 and Battacharyya et al 2015). The seaweed extracts contain some plant growth hormones, regulators, promoters, macro and micro nutrients, carbohydrates, amino acids, antibiotics, auxins, gibberellins, cytokinins, natural enzymes and vitamins consequently which enhance yield and quality as reported by Shaaban (2011), Ordog et al (2004) and Jensen (2004). Van Staden et al (1994) tested the effect of seaweed extract at $0.0,0.5,1.0$ and $2.0 \mathrm{ml} / \mathrm{L}$ as foliar application or soil drench on Marigold (Tagetespatula) and found that $1.0 \mathrm{ml} / \mathrm{L}$ increased significantly plant height and number of flowers/plant. However, the application method was not effective. In the study conducted by Jones et al (1998), seaweed foliar application on sturt's desert pea flowers (Swainsona formosa) increased significantly chlorophyll content while the increase in vase life was not significant. In the study of Crouch (1990)seaweed extracts applied as a soil drench, improved plant vigor, increased significantly shoot and root fresh weights of tomato plants, moreover, plants treated with a foliar spray showed improved total yield by over $10 \%$. In this respect, Abdel Mawgoud et al (2010) reported that seaweed extract at 1, 2, $3 \mathrm{~g} / \mathrm{l}$ increased plant height, number of branches and fresh weight of cucumber. The application of seaweed extract as foliar spray 
at $0.5 \%$ increased plant height, number of branches and total carbohydrates of Tageteserecta while spraying with $0.1 \%$ increased plant length, total chlorophyll, N, P and $\mathrm{K}$ persentages specially when used with only $50 \%$ of the recommended chemical fertilization rate (Sridhar and Rengasamy, 2011). Seaweed liquid fertilizer increased significantly number of shoots, fresh and dry weight of plant, chlorophyll a, b, total chlorophyll, number of flowers/plant and seed yield of Vigna radiate $\mathrm{L}$. as mentioned by Renuka et al (2011). Moreover, Sarhan (2011) found that two seaweed extracts at $3 \mathrm{ml} / \mathrm{L}$ increased plant height, fresh weight/plant and number of shoots of watermelon. Seaweed extracts increased chlorophyll and carotenoids contents when used at $20 \%$ as foliar spray on bean, barley and tomato (Hussein et al 2011). They added also that seaweed extracts increased significantly shoot weight and chlorophyll content in Zeamays L. when sprayed twice at $1 \mathrm{~cm} / \mathrm{l}$. Mancuso et al (2006) noted increased uptake of $\mathrm{N}, \mathrm{P}, \mathrm{K}$ and $\mathrm{Mg}$ in grapevines and cucumber with application of seaweed extract, they added also that the presence of bioactive substances in seaweed extract improves stomata uptake efficiency in treated plants compared to non-treated plants. Machado et al (2014) applied a biostimulant consisted of cytokinin $(90 \mathrm{mg} / \mathrm{L})$, auxin (50 mg/L) and gibberellic acid (50 mg/L) as foliar spray at $0,3,6,9,12$ and $15 \mathrm{ml} / \mathrm{L}$ increased significantly plant length, number of flowers and flavinoids content of marigold (Calendula officinalis L.). Foliar application of seaweed extract at $10 \%$ increased nutrient uptake $\mathrm{N}, \mathrm{P}, \mathrm{K}, \mathrm{Fe}, \mathrm{Mn}$ and $\mathrm{Mg}$ in Vigna mungo L. as reported by Jadhao et al (2015) and Battacharyya et al (2015). Mohy Eldin (2015) concluded that the seaweed liquid fertilizers are effective with low cost that can be promoted as eco-friendly bio fertilizers in Egypt since it increased growth and pigments of wheat seedlings. In a recent study, Venkata et al (2015) investigated the effect of different concentrations of seaweed on productivity of cow pea and found that plant height, number of branches and yield increased by $10 \%$ as compared with control. In this respect, Dirya et al (2015) reported that seaweed extract was found effective in increasing the biomass growth of roots, shoots, number of leaves, flowers and yield of Solanum melongena at 5\% when applied as foliar spray. Recently, seaweed extract at $1 \mathrm{~cm} / \mathrm{L}$ as foliar spray improved plant height, number of branches and number and diameter of floresences in Calendula officinalis under saline and non saline conditions as found by
Nofal et al (2015). Therefore, the main objective of this study was to evaluate the application method of different concentrations of seaweed extracts in enhancing growth, flowering and nutrient content of calendula officinalis plants.

\section{MATERIALS AND METHODS}

\section{Location and duration}

This study was conducted in Faculty of Agriculture, Ain Shams University, Shoubra El Khima, Qalubia governorate during the two successive seasons of 2012-2013 and 2013-2014.

\section{Plant material}

Seeds of local origin of Pot marigold (Calendula officinalis L.) were obtained from the ornamental plants nursery, Ministry of Irrigation, El-Kanater El-khairia, Qalubia

\section{Seaweed extract}

A commercial seaweed extract containing natural bioactive substances like vitamins, free amino acids, hormones and alginates processed out of selected seaweeds (Sargassum sp., Ascophyllum nodosum and luminaria $s p$.). Seaweed extract was kindly donated by the Union for Agricultural Development (UAD) company, Cairo, Egypt. The chemical composition of commercial seaweed extract is presented in Table (A).

Seeds of local origin of pot marigold were sown on September $10^{\text {th }}$ and $15^{\text {th }}$ in the first and second growing seasons, respectively in $30 \mathrm{~cm}$ plastic pots as a nursery. Pots were filled with a medium which contains a mixture of peat moss, sand and vermiculite $(2: 1: 1$ by volume) and seeds were covered with $0.5 \mathrm{~cm}$ of the medium and irrigated. Then pots were kept in the uncontrolled greenhouse.

Seedlings were pricked out in $25 \mathrm{~cm}$ plastic pots filled beforehand with the same above medium as one seedling per pot on October $20^{\text {th }}$ and $25^{\text {th }}$ in the first and second growing seasons, respectively.

\section{Experimental seaweed treatments}

The tested seaweed concentrations for both foliar application and soil drench were prepared from powder seaweed extract in detail, $0.5 \mathrm{~g}, 1 \mathrm{~g}$ and $1.5 \mathrm{~g}$ were each dissolved in 1 Litre of water to prepare 500, 1000 and 1500 ppm respectively, each 
Table A. Chemical and biochemical analysis of a commercial seaweed extract powder

\begin{tabular}{|ll|ll|ll|}
\hline \multicolumn{2}{|c|}{ Organic matter } & \multicolumn{2}{c|}{ Growth regulators } & \multicolumn{2}{c|}{ Macro and micro elements } \\
\hline Total amino acid & $6 \%$ & IAA & $0.03 \%$ & Organic $(\mathrm{N})$ & $3.12 \%$ \\
Carbohydrates & $35 \%$ & Cytokinins & $0.02 \%$ & $\mathrm{P}_{2} \mathrm{O}_{5}$ & $2.61 \%$ \\
Alginic acid & $10 \%$ & & & $\mathrm{k}_{2} \mathrm{O}$ & $4.71 \%$ \\
Manitol & $4 \%$ & & & $\mathrm{Ca}$ & $0.25 \%$ \\
Betaines & $0.04 \%$ & & $\mathrm{~S}$ & $3.56 \%$ \\
& & & & $\mathrm{Mg}$ & $0.58 \%$ \\
& & & & $\mathrm{Fe}$ & $150 \mathrm{ppm}$ \\
& & & $\mathrm{Zn}$ & $70 \mathrm{ppm}$ \\
& & & & $\mathrm{Mn}$ & $13 \mathrm{ppm}$ \\
& & & & $\mathrm{B}$ & $60 \mathrm{ppm}$ \\
& & & & & \\
& & & & & \\
\end{tabular}

concentration was studied twice i.e., either foliar spray or soil drench The control treatment was tap water. Treatments were applied three times: the first application was applied three weeks from transplanting followed by a second application administered one month after and the third one applied one month late. All agricultural practices, i.e. irrigation, fertilization, pest and disease control were carried out as recommended in the leaflet of Horticulture Research Institute, Agriculture Research Center (ARC), Ministry of Agriculture.

\section{Data Recorded}

\section{Vegetative growth parameters}

A random sample of three plants from each replicate for each treatment was taken at the beginning of flowering for vegetative growth data, i.e. plant height $(\mathrm{cm})$, number of shoots/plant and fresh weight $(\mathrm{g}$ ) of foliage aerial parts ( stem, leaves and flowers).

\section{Flowering traits}

Number of flowers per plant, flower stalk length $(\mathrm{cm})$ and flower diameter $(\mathrm{cm})$ were recorded.

\section{Postharvest flower vase life}

Vase life was determined whereas, flowers were harvested between 7:00 Am and 10:00 Am at the optimum stage of development (outer ring of ray florets opened). The lower half of the stem was stripped of its leaves and then placed into vases as ten flowers per replicate within 5 minutes of being cut. Vases were filled with tap water. Flowers were discarded daily until reaching $50 \%$ of their number based on petal wilt, turning brown or stem bent as described by Erin et al (2010).

\section{Chemical analysis}

A representative sample of 100 grams of plant foliage was taken, and oven dried. The total nitrogen percentage was determined in dry samples using micro-kjeldahl apparatus according to FAO (1980). Phosphorus percentage was estimated using a colorimetric method according to the method described by Jackson (1976). Potassium was evaluated using the flame photometer device as explained by Brown and Lilleland (1946). Determination of potassium and sodium in plant material and soil extract by flame photometry. Proc. Amer. Soc., [C.F. Hort. Sci., 73: 813]. Chlorophyll 'a' and chlorophyll 'b' were estimated marigold according to the method set out by Arnon (1949). Total carotenoids were determined as $\mathrm{mg} / 100 \mathrm{~g}$ fresh weight from flower petals by using a colori- 
metric method stated by A.O.A.C. (2005). Total carbohydrates percentage was estimated according to Dubois et al (1956).

\section{Experimental Design}

Treatments were arranged in a randomized complete block design (RCBD) with three replicates for each treatment. Each block contained the seven seaweed treatments that were allocated randomly. Each replicate contained eight pots, each pot containing one plant.

\section{Statistical Analysis}

Data were statistically analyzed using the analysis of variance (ANOVA) described by Snedecor and Cochran, (1990). The method of Duncan's multiple range tests was applied for the comparison between means according to (Waller and Duncan, 1969).

\section{RESULTS AND DISCUSSION}

\section{1- Plant height}

Results presented in Table (1) clearly indicate that all tested treatments of seaweed extract increased significantly calendula plant height as compared with control plants. However, the highest values were obtained in plants sprayed with $1500 \mathrm{ppm}$ of seaweed extract in the two tested seasons in addition to those administed with 1500 ppm as soil drench in the second season. The results agree with those found by Abdel-Mawgoud et al (2010), Sridher and Rengasamy (2011), Sarhan (2011) and Venkata (2015). Such increament in plant height may be attributed to the plant growth hormones, auxins, gibberellins and plant nutrients present in the seaweed extracts as mentioned by Shaaban (2011), Ordog et al (2004) and Jensen (2004).

\section{2- Number of shoots / plant}

Results presented in Table (1) indicate also that foliar spray of seaweed extract at $500 \mathrm{ppm}$ and soil drench at $1000 \mathrm{ppm}$ showed the highest significant values of number of shoots / plant without significant differences between them in the first season, nevertheless the control treatment gave the lowest value. In the second season, a significant increment in shoot number / plant was found using 500 ppm of seaweed extract as foliar spray as compared to all tested treatments. Our results are in the same direction with those obtained by Crouch (1990), Abdel-Mawgoud et al (2010), Sarhan (2011), Renuka et al (2011) and Venkata et al (2015).

Such increment in shoot number / plant due to seaweed application may be attributed to that seaweed extracts contain some plant growth hormones, macro and micro nutrients, carbohydrates, amino acids, antibiotics, cytokinins, auxins, natural enzymes and vitamins as reported by Shaaban (2011, Ordog et al (2004) and Jensen (2004). Such auxins and cytokinins promote growth via rapidly speeding up the process of cell division. They allow to areas of elongation where they allow the walls of cells to stretch. (Johri and Mitra, 2001).

\section{3- Number of flowers / plant}

Results in Table (2) indicate that the high concentrations of seaweed extract, i.e. 1000 and 1500 ppm showed significant increments in number of flowers / plant for pot marigold in the two tested seasons regardless of the application method when compared to the control treatment. In this respect, foliar spray of seaweed extract at 1500 ppm reflected a significant increases in number of flowers / plant in both the two tested seasons without significant differences with plants sprayed with 1000 ppm or soil drenched with 1500ppm in the second season only. However, the control treatment showed the lowest values in the two experimental seasons. Such results are in the same line with those obtained by Sridhar \& Rengasamy (2011) and Dirya et al (2015)

The increment in number of flower / plant treated with seaweed extract may be due to the increased plant height and high number of shoots / plant in these plants as shown in Table (1) in addition to the plant growth regulators in the seaweed extract as stated in Table (A).

\section{4- Flower stalk length}

In Table (2), data of results reveal that spraying pot marigold plants with 500 ppm of seaweed extract showed higher significant values of flower stalk length as compared with non-treated plants in the two experimental seasons. These results are in agreement with those of Diryaet al (2015). This increment may be attributed to the stimulant effect of seaweed extract because it contains many growth promoters such as auxins, gibberellins and cytokinins. 
Table 1. Effect of application method and concentration of seaweed extract on plant height and number of shoots/plant for Calendula officinalis plants during 2012/2013 and 2013/2014 seasons

\begin{tabular}{|c|c|c|c|c|}
\hline \multirow{2}{*}{ Treatments (ppm) } & \multicolumn{2}{|c|}{ Plant height (cm) } & \multicolumn{2}{c|}{ No. of shoots/plant } \\
\cline { 2 - 5 } & $\mathbf{2 0 1 2 / 2 0 1 3}$ & $\mathbf{2 0 1 3 / 2 0 1 4}$ & $\mathbf{2 0 1 2 / 2 0 1 3}$ & $\mathbf{2 0 1 3 / 2 0 1 4}$ \\
\hline Control & $30.77 \mathrm{~d}$ & $30.20 \mathrm{~d}$ & $7.53 \mathrm{~d}$ & $11.10 \mathrm{~cd}$ \\
F.S.500 & $43.63 \mathrm{c}$ & $40.07 \mathrm{c}$ & $12.77 \mathrm{bc}$ & $17.83 \mathrm{a}$ \\
S.D.500 & $43.07 \mathrm{c}$ & $44.40 \mathrm{~b}$ & $13.53 \mathrm{bc}$ & $12.10 \mathrm{bc}$ \\
F.S.1000 & $49.30 \mathrm{~b}$ & $44.97 \mathrm{~b}$ & $12.77 \mathrm{bc}$ & $13.83 \mathrm{~b}$ \\
S.D.1000 & $51.73 \mathrm{~b}$ & $47.77 \mathrm{~b}$ & $14.07 \mathrm{ab}$ & $9.67 \mathrm{~d}$ \\
F.S.1500 & $63.77 \mathrm{a}$ & $55.87 \mathrm{a}$ & $15.30 \mathrm{a}$ & $13.63 \mathrm{~b}$ \\
S.D.1500 & $49.63 \mathrm{~b}$ & $55.07 \mathrm{a}$ & $12.20 \mathrm{c}$ & $10.63 \mathrm{~cd}$ \\
\hline
\end{tabular}

F.S. = Foliar spray S.D $=$ Soil drench

Values in the same column followed by the same letter (s) are not statistically different according to Duncan's multiple range tests.

Table 2. Effect of application method and concentration of seaweed extract on number of flowers/plant and flower stalk length (cm) for Calendula officinalis plants during 2012/2013 and 2013/2014 seasons

\begin{tabular}{|c|c|c|c|c|}
\hline \multirow{2}{*}{ Treatments (ppm) } & \multicolumn{2}{|c|}{ Number of flowers/plant } & \multicolumn{2}{c|}{ Flower stalk length (cm) } \\
\cline { 2 - 5 } & $\mathbf{2 0 1 2 / 2 0 1 3}$ & $\mathbf{2 0 1 3 / 2 0 1 4}$ & $\mathbf{2 0 1 2 / 2 0 1 3}$ & $\mathbf{2 0 1 3 / 2 0 1 4}$ \\
\hline Control & $11.17 \mathrm{c}$ & $11.40 \mathrm{c}$ & $17.50 \mathrm{~d}$ & $19.60 \mathrm{~cd}$ \\
F.S.500 & $14.30 \mathrm{~b}$ & $13.53 \mathrm{c}$ & $33.77 \mathrm{a}$ & $29.63 \mathrm{a}$ \\
S.D.500 & $14.73 \mathrm{~b}$ & $18.20 \mathrm{~b}$ & $20.53 \mathrm{~cd}$ & $16.70 \mathrm{~d}$ \\
F.S.1000 & $16.60 \mathrm{~b}$ & $24.30 \mathrm{a}$ & $27.93 \mathrm{~b}$ & $22.20 \mathrm{bc}$ \\
S.D.1000 & $15.53 \mathrm{~b}$ & $22.83 \mathrm{a}$ & $22.00 \mathrm{c}$ & $25.87 \mathrm{ab}$ \\
F.S.1500 & $20.77 \mathrm{a}$ & $21.83 \mathrm{a}$ & $22.20 \mathrm{c}$ & $20.97 \mathrm{c}$ \\
S.D.1500 & $15.07 \mathrm{~b}$ & $16.97 \mathrm{~b}$ & $27.20 \mathrm{~b}$ & $22.17 \mathrm{bc}$ \\
\hline
\end{tabular}

F. S. = Foliar spray S.D = Soil drench

Values in the same column followed by the same letter (s) are not statistically different according to Duncan's multiple range tests.

\section{5- Vase life}

As for the effect of seaweed extract on vase life, i.e. postharvest flower life results in Table (3) revealed that $1000 \mathrm{ppm}$ as soil drench and 1500 ppm as foliar spray led to a significant increment in vase life of pot marigold flowers as compared with all other tested treatments. The results are in agreement with those of Jones et al (1998) who mentioned that the vase life of Sturt's Desert Bea flowers increased by five days when treated with seaweed concentrate.

\section{6- Flower diameter}

The addition of seaweed extract at $500 \mathrm{ppm}$ as soil drench to Calendula plants resulted in a significant increment in the two tested seasons. The control plants showed the lowest value flower diameter in the two tested seasons. The results are similar to those reported by Norrie and Keathley (2006), Delucia and Vecchietti (2012) and Nofal et al (2015). 
Table 3. Effect of application method and concentration of seaweed extract on vase life (day) and flower diameter (cm) for Calendula officinalis plants during 2012/2013 and $2013 / 2014$ seasons

\begin{tabular}{|c|c|c|c|c|}
\hline \multirow{2}{*}{ Treatments (ppm) } & \multicolumn{2}{|c|}{ Vase life (day) } & \multicolumn{2}{c|}{ Flower diameter (cm) } \\
\cline { 2 - 5 } & $\mathbf{2 0 1 2 / 2 0 1 3}$ & $\mathbf{2 0 1 3 / 2 0 1 4}$ & $\mathbf{2 0 1 2 / 2 0 1 3}$ & $\mathbf{2 0 1 3 / 2 0 1 4}$ \\
\hline Control & $6.00 \mathrm{c}$ & $4.67 \mathrm{~d}$ & $4.47 \mathrm{~d}$ & $4.53 \mathrm{~d}$ \\
F.S.500 & $6.67 \mathrm{~b}$ & $6.67 \mathrm{a}$ & $5.27 \mathrm{~b}$ & $5.20 \mathrm{c}$ \\
S.D.500 & $6.00 \mathrm{c}$ & $6.00 \mathrm{bc}$ & $5.80 \mathrm{a}$ & $6.10 \mathrm{a}$ \\
F.S.1000 & $6.00 \mathrm{c}$ & $5.67 \mathrm{c}$ & $5.47 \mathrm{~b}$ & $5.63 \mathrm{~b}$ \\
S.D.1000 & $7.33 \mathrm{a}$ & $6.67 \mathrm{a}$ & $5.00 \mathrm{c}$ & $4.73 \mathrm{~d}$ \\
F.S.1500 & $7.33 \mathrm{a}$ & $6.33 \mathrm{ab}$ & $4.83 \mathrm{c}$ & $5.27 \mathrm{c}$ \\
S.D.1500 & $6.00 \mathrm{c}$ & $6.33 \mathrm{ab}$ & $4.87 \mathrm{c}$ & $5.50 \mathrm{~b}$ \\
\hline
\end{tabular}

F. S. = Foliar spray S.D = Soil drench

Values in the same column followed by the same letter (s) are not statistically different according to Duncan's multiple range test.

\section{7- Carbohydrates content}

Concerning carbohydrates content, data resulted presented in Table (4) denate that using foliar spray of seaweed extract at 500 ppm gave the highest values in the two tested seasons without significant differences between them and those of the control plants as well as plants that had received 1500 ppm as soil drench. Our results are true with those obtained by Sridhar and Rengasamy (2010) and Venkata et al (2015). These results may be due to the positive effect of seaweed extract on plant height, number of shoots, flower stalk length and fresh weight / plant, such plants showed high photosynthesis and net assimilation rate and finally produced more carbohydrates content.

\section{8- Vegetative fresh weight}

With respect to vegetative fresh weight per plant, results in Table (4) show clearly that seaweed extract at $1500 \mathrm{ppm}$ as foliar spray showed the highest values; on the other hand, control plants indicated the lowest values in the two tested seasons. Such results are in the same line with those of Crouch (1990), Norrie and Keathley (2006), Hussein et al (2011), and Delucia and Vecchietti (2012).
This increment in vegetative fresh weight/plant due to seaweed application may be due to the positive effect of seaweed extract on increasing most vegetative growth characters i.e., plant height, number of shoots and flower stalk length as seaweed extract contains many growth regulators, macro and micro nutrients as found by Shaaban (2011), Ordog et al (2004) and Jensen (2004).

\section{9- Chlorophyll content}

Data shown in Table (5) indicate that there was a slight significant effect for seaweed extract on chlorophyll (a) content. Moreover, the highest values of chlorophyll (a) content were recorded when plants were sprayed with 500 ppm in the first season. Meanwhile, soil drench of seaweed at 1000 ppm gave the highest values in the second season. Regarding chlorophyll (b) content, the results in Table (5) showed no clear effect for seaweed extract application as for total chlorophyll. Results in Table (5) showed that the highest values were found when plants were sprayed with 500 ppm in the first season and with the same concentration but as soil drench in the second season. Our results confirm those of Jones et al (1998), Sridhar and Rangasamy (2010), Renuka et al (2011), Sarban (2011) and Delucia and Vecchietti (2012). 
Table 4. Effect of application method and concentration with seaweed extract on carbohydrates $(\mathrm{mg} / \mathrm{g})$ and fresh weight/plant $(\mathrm{g})$ for Calendula officinalis plants during 2013 and 2014 seasons

\begin{tabular}{|c|c|c|c|c|}
\hline \multirow{2}{*}{ Treatments (ppm) } & \multicolumn{2}{|c|}{ Total Carbohydrates (mg/g) } & \multicolumn{2}{c|}{ Fresh weight/plant (g) } \\
\cline { 2 - 5 } & $\mathbf{2 0 1 2 / 2 0 1 3}$ & $\mathbf{2 0 1 3 / 2 0 1 4}$ & $\mathbf{2 0 1 2 / 2 0 1 3}$ & $\mathbf{2 0 1 3 / 2 0 1 4}$ \\
\hline Control & $22.90 f$ & $36.44 \mathrm{c}$ & $566.7 \mathrm{f}$ & $494.3 \mathrm{f}$ \\
F.S.500 & $57.81 \mathrm{a}$ & $55.20 \mathrm{a}$ & $716.7 \mathrm{~d}$ & $539.3 \mathrm{e}$ \\
S.D.500 & $38.34 \mathrm{~d}$ & $40.52 \mathrm{~b}$ & $1183.3 \mathrm{~b}$ & $888.7 \mathrm{~b}$ \\
F.S.1000 & $37.77 \mathrm{~d}$ & $41.43 \mathrm{~b}$ & $816.7 \mathrm{c}$ & $444.3 \mathrm{~g}$ \\
S.D.1000 & $31.45 \mathrm{e}$ & $55.68 \mathrm{a}$ & $833.3 \mathrm{c}$ & $854.3 \mathrm{c}$ \\
F.S.1500 & $48.31 \mathrm{c}$ & $23.14 \mathrm{~d}$ & $1250.0 \mathrm{a}$ & $1005.2 \mathrm{a}$ \\
S.D.1500 & $52.63 \mathrm{~b}$ & $54.25 \mathrm{a}$ & $691.7 \mathrm{e}$ & $722.0 \mathrm{~d}$ \\
\hline
\end{tabular}

F. S. = Foliar spray S.D $=$ Soil drench

Values in the same column followed by the same letter (s) are not statistically different according to Duncan's multiple range test.

Table 5. Effect of application method and concentration of seaweed extract on chlorophyll and carotenoid contents (mg/100 g fresh weight) for Calendula officinalis plants during 2012/2013 and 2013/2014 seasons

\begin{tabular}{|c|c|c|c|c|c|c|c|c|}
\hline \multirow{3}{*}{$\begin{array}{l}\text { Treatments } \\
\qquad(\mathrm{ppm})\end{array}$} & \multicolumn{2}{|c|}{ Chlorophyll (a) } & \multicolumn{2}{|c|}{ Chlorophyll (b) } & \multicolumn{2}{|c|}{ Total chlorophyll } & \multicolumn{2}{|c|}{ Carotenoids } \\
\hline & \multicolumn{8}{|c|}{ (mg/100 g fresh weight) } \\
\hline & 2012/2013 & $2013 / 2014$ & 2012/2013 & $2013 / 2014$ & $2012 / 2013$ & 2013/2014 & $2012 / 2013$ & $2013 / 2014$ \\
\hline Control & $0.62 \mathrm{c}$ & $0.64 b$ & $0.66 a-d$ & $0.29 c$ & $1.28 \mathrm{~cd}$ & $0.93 \mathrm{de}$ & $7.36 \mathrm{~d}$ & $6.33 c$ \\
\hline F.S. 500 & $1.51 \mathrm{a}$ & $0.44 c$ & $0.79 a-c$ & $0.85 b$ & $2.31 \mathrm{a}$ & $1.28 \mathrm{~cd}$ & $13.53 \mathrm{bc}$ & $12.90 \mathrm{~b}$ \\
\hline S.D. 500 & $0.71 \mathrm{c}$ & $0.63 b$ & $0.37 \mathrm{~cd}$ & $1.57 \mathrm{a}$ & $1.08 \mathrm{de}$ & $2.20 \mathrm{a}$ & $16.92 a$ & $15.81 a$ \\
\hline F.S. 1000 & $1.16 \mathrm{~b}$ & $0.60 \mathrm{~b}$ & $0.46 b-d$ & $0.24 c$ & $1.62 \mathrm{bc}$ & $0.85 \mathrm{e}$ & $13.55 \mathrm{bc}$ & $17.15 a$ \\
\hline S.D. 1000 & $0.57 c$ & $0.84 a$ & $0.27 d$ & $0.65 b c$ & $0.84 \mathrm{e}$ & $1.49 b c$ & $12.20 \mathrm{c}$ & $16.16 a$ \\
\hline F.S. 1500 & $0.76 c$ & $0.68 b$ & $0.98 a$ & $1.08 \mathrm{~b}$ & $1.74 b$ & $1.76 \mathrm{~b}$ & $14.29 b$ & $13.50 \mathrm{~b}$ \\
\hline S.D. 1500 & $0.73 c$ & $0.72 b$ & $0.89 a b$ & $0.23 c$ & $1.61 b c$ & $0.95 \mathrm{de}$ & $14.81 \mathrm{~b}$ & $16.13 a$ \\
\hline
\end{tabular}

F. S. = Foliar spray

S.D $=$ Soil drench

Values in the same column followed by the same letter (s) are not statistically different according to Duncan's multiple range test.

\section{0- Total carotenoids}

Results presented in Table (5) point out clearly that the addition of seaweed extract at 500 ppm as soil drench showed the highest significant values of total carotenoids in calendula plants in the first season as compared with all other tested treatments. However, in the second season, all tested seaweed treatments increased significantly total carotenoids as compared with the control. The results here agree with those of Hussein et al (2011), Machado et al (2014) and Mohy El-Din (2015).

\section{1- Nitrogen, phosphorus and potassium con-} tent

All used concentrations of seaweed extract by the two tested application methods increased significantly nitrogen percentage in calendula plants 
as compared with the control (Table 6). Concerning the effect of seaweed extract on phosphorus percentage, data in Table (6) revealed that the lowest used concentration i.e., 500 ppm either foliar spray or soil drench resulted in the highest significant values in the two tested seasons. Moreover no significant differences were detected between control treatment and most of the used treatments in both seasons.

It is clear from results tabulated in Table (6) that all used concentrations of seaweed extract increased significantly potassium percentage than the control in the two tested season when used as foliar spray or as soil drench. In this regard, no significant differences were detected in most of seaweed application treatments. The results are in agreement with those of Battacharyya et al (2015) and Jadhau et al (2015).

Such increase in microelements due to seaweed application may be attributed to improving stomata uptake efficiency in the treated plants as mentioned by Mancuso et al (2006).

\section{2- Fe, Zn and Mncontent}

The highest used concentration of seaweed extract (1500 ppm) resulted in the highest Fe content in pot marigold foliage in the two tested seasons in addition to the control treatment in the second season with significant differences between them (Table 7). As regards to $\mathrm{Zn}$ content, results in Table (7) showed also that calendula plants treated with 500 ppm as foliar spray showed the highest values in the first season without significant difference among them. While in the second season, the highest value was detected to those plants received $1000 \mathrm{ppm}$ as soil drench. Control plants gave the highest values in the two experimental seasons in addition to those treated with 1500 ppm as soil drench in the second season. Seaweed extract had no significant effect on Mn content of calendula plants. Such results are in the same line with those obtained by Battacharyya et al (2015) who found no effect of seaweed on Mn concentration on Spinach.

Table 6. Effect of application method and concentration of seaweed extract on nitrogen, phosphorus and potassium content as percentages in foliage samples of Calendula officinalis plants during 2012/2013 and 2013/2014 seasons

\begin{tabular}{|c|c|c|c|c|c|c|}
\hline \multirow{2}{*}{ Treatments (ppm) } & \multicolumn{2}{|c|}{$\mathbf{N}(\%)$} & \multicolumn{2}{c|}{$\mathbf{P}(\%)$} & \multicolumn{2}{c|}{ K (\%) } \\
\cline { 2 - 7 } & $\mathbf{2 0 1 2 / 2 0 1 3}$ & $\mathbf{2 0 1 3 / 2 0 1 4}$ & $\mathbf{2 0 1 2 / 2 0 1 3}$ & $\mathbf{2 0 1 3 / 2 0 1 4}$ & $\mathbf{2 0 1 2 / 2 0 1 3}$ & $\mathbf{2 0 1 3 / 2 0 1 4}$ \\
\hline Control & $1.05 \mathrm{c}$ & $1.06 \mathrm{c}$ & $0.19 \mathrm{~d}$ & $0.18 \mathrm{~d}$ & $0.29 \mathrm{~d}$ & $0.29 \mathrm{c}$ \\
F.S.500 & $2.42 \mathrm{~b}$ & $2.46 \mathrm{~b}$ & $1.52 \mathrm{~b}$ & $1.41 \mathrm{~b}$ & $1.85 \mathrm{c}$ & $1.56 \mathrm{~b}$ \\
S.D.500 & $2.99 \mathrm{a}$ & $2.99 \mathrm{a}$ & $1.94 \mathrm{a}$ & $1.71 \mathrm{a}$ & $1.87 \mathrm{c}$ & $1.67 \mathrm{~b}$ \\
F.S.1000 & $2.81 \mathrm{a}$ & $2.79 \mathrm{a}$ & $0.39 \mathrm{~d}$ & $0.41 \mathrm{~d}$ & $2.71 \mathrm{a}$ & $2.70 \mathrm{a}$ \\
S.D.1000 & $2.24 \mathrm{~b}$ & $2.26 \mathrm{~b}$ & $0.31 \mathrm{~d}$ & $0.27 \mathrm{~d}$ & $2.29 \mathrm{~b}$ & $2.30 \mathrm{ab}$ \\
F.S.1500 & $2.99 \mathrm{a}$ & $3.01 \mathrm{a}$ & $0.96 \mathrm{c}$ & $0.95 \mathrm{c}$ & $2.46 \mathrm{~b}$ & $1.80 \mathrm{~b}$ \\
S.D.1500 & $2.91 \mathrm{a}$ & $2.92 \mathrm{a}$ & $0.27 \mathrm{~d}$ & $0.26 \mathrm{~d}$ & $2.43 \mathrm{~b}$ & $1.44 \mathrm{ab}$ \\
\hline
\end{tabular}

F.S. = Foliar spray S.D $=$ Soil drench

Values in the same column followed by the same letter (s) are not statistically different according to Duncan's multiple range test. 
Table 7. Effect of application method and concentration of seaweed extract on iron, zinc and manganese (mg/l) for Calendula officinalis plants during 2013 and 2014 seasons

\begin{tabular}{|c|c|c|c|c|c|c|}
\hline \multirow{2}{*}{ Treatments (ppm) } & \multicolumn{2}{|c|}{ Fe (mg/l) } & \multicolumn{2}{c|}{ Zn (mg/l) } & \multicolumn{2}{c|}{ Mn (mg/l) } \\
\cline { 2 - 7 } & $\mathbf{2 0 1 2 / 2 0 1 3}$ & $\mathbf{2 0 1 3 / 2 0 1 4}$ & $\mathbf{2 0 1 2 / 2 0 1 3}$ & $\mathbf{2 0 1 3 / 2 0 1 4}$ & $\mathbf{2 0 1 2 / 2 0 1 3}$ & $\mathbf{2 0 1 3 / 2 0 1 4}$ \\
\hline Control & $32.55 \mathrm{e}$ & $40.00 f$ & $14.67 \mathrm{~d}$ & $6.51 \mathrm{f}$ & $29.30 \mathrm{a}$ & $31.50 \mathrm{a}$ \\
F.S. 500 & $51.63 \mathrm{c}$ & $53.98 \mathrm{e}$ & $21.50 \mathrm{a}$ & $16.83 \mathrm{~d}$ & $27.33 \mathrm{c}$ & $28.53 \mathrm{~b}$ \\
S.D.500 & $33.68 \mathrm{e}$ & $62.58 \mathrm{~d}$ & $18.67 \mathrm{~b}$ & $18.67 \mathrm{c}$ & $28.70 \mathrm{ab}$ & $27.63 \mathrm{bc}$ \\
F.S.1000 & $56.25 \mathrm{bc}$ & $78.18 \mathrm{c}$ & $17.00 \mathrm{c}$ & $21.33 \mathrm{~b}$ & $27.60 \mathrm{bc}$ & $28.03 \mathrm{~d}$ \\
S.D.1000 & $60.62 \mathrm{~b}$ & $67.80 \mathrm{~d}$ & $21.50 \mathrm{a}$ & $22.67 \mathrm{a}$ & $27.27 \mathrm{c}$ & $25.83 \mathrm{~d}$ \\
F.S.1500 & $80.25 \mathrm{a}$ & $105.33 \mathrm{~b}$ & $19.83 \mathrm{ab}$ & $16.17 \mathrm{~d}$ & $29.37 \mathrm{a}$ & $27.33 \mathrm{bc}$ \\
S.D.1500 & $39.90 \mathrm{~d}$ & $125.58 \mathrm{a}$ & $18.83 \mathrm{~b}$ & $12.12 \mathrm{e}$ & $26.70 \mathrm{c}$ & $26.67 \mathrm{~cd}$ \\
\hline
\end{tabular}

F.S. $=$ Foliar spray

S.D $=$ Soil drench

Values in the same column followed by the same letter (s) are not statistically different according to Duncan's multiple range test.

\section{Conclusion and recommendation}

The study here with recommends using 500 ppm of seaweed extract to increase flower diameter and flower stalk length as foliar spray or as soil drench to increase carotein content in flowers when Pot marigold is used for medicinal purposes. Whereas, if used as a cut-flower for decoration purposes the study concludes also that $1500 \mathrm{ppm}$ as foliar spray increase plant height, flower number and vase life.

\section{REFERENCES}

A.O.A.C, 2005. Official methods of analysis. $15^{\text {th }}$ ed. Association Agricultural Chemists. $12^{\text {th }}$ Ed., Washington, D.C., USA.

Abdel-Mawgoud, A.M.R., Tantaway, A.S., Hafez, M.M. and Habib, H.A. 2010. Seaweed extract improves growth, yield and quality of different watermelon hybrids. Research J. Agric. and Biolog. Sci., 6(2), 161-168.

Arnon, D.L. 1949. Copper enzymes in isolated chloroplast, polyphenol oxidase in Beta vulgarise. Plant Physiology, 2, 1-15.

Battacharyya, D., Babgohari, M.Z., Rathor, P. and Prithiriraj, B. 2015. Seaweed extract as biostimulants in horticulture. Scientia Horticulturae. 196, 39-48.

Brown, J.D. and Lilleland, O. 1946. Determination of potassium and sodium in plant material and soil extract by flame photometry. Proc. Amer. Soc., J. Hort. Sci., 73, 813.

Crouch, I.J. 1990. The effect of seaweed concentrate on plant growth. Ph.D. Thesis. Dept. of Botany, Faculty of Science, University of Natal, pietermari Tzburg.

Delucia, B. and Vecchietti, L. 2012. Type of bio stimulant and application method effects on stem quality and root system growth in L.A. Lily. Europ. J. Hort. Sci., 77(1), 10-15.

Dirya, K., Roja, N.M. and Padal, S.B. 2015. Effect of seaweed liquid fertilizer of sargassum wightiion germination, growth and productivity of brinjal Solanum melongena. International J. of Advanced Research in Science, Engineering and Technology 2(10), 868-871.

Dubois, M., Gilles, K.A., Hamilton, J.K., Rebers, P.A. and Smith, F. 1956. Colourimetric method for determination of sugars and related substances. Ann. Chem., 28, 350.

Erin, M.R. Clark, Jonhn, M. Dole, Alicain S. Carlson, Erin P. Moody, Ingram F. McCall, Frankie L. Fanelli and William C. Fonteno, 2010. Hort. Technology 20(6), 101- 102.

FAO, 1980. Soil and Plant Testing and Analysis. FAO Soil Bulletin, 38(1), 250.

Hussien, A.A., Ismail, A.A. and Sabra, F.S. 2011. Bioactive substances extracted from seaweeds as a biocontrol agent's effects and identification. J. Agric. Res. Kafer El-sheikh Univ. 37(1), 183-208. 
Jackson, M.L. 1973. Soil chemical analysis Prentice-Hall of India private limited M-97, New Delhi, India, 498 p.

Jadhao, R.G., Chaudhary, D.R., Khadse, V.A. and Zodape, S.T. 2015. Utilization of seaweed in enhancing productivity and quality of black gram (Vigna mungo L. Hepper) for sustainable agriculture. Indian Journal of Natural Products and Resources, 6(1), 16-22.

Jensen, E. 2004. Fact or fancy.From the organic broad caster. Midwest organic and Sustainable Education. 12(3), 164-170.

Johri, M.M. and Mitra, D. 2001. Action of plant hormones. Curr. Sci., (80), 199-205.

Jones, P.N., Taja, A.M. and Faint, M.J. 1998. The effect of Natrakelp (seaweed) concentrate and cultar on the vas life of sturt's desert pea flowers (Swainsona formosa). Acta Hort. 454, 383390.

Machado, V.P., Pacheco, A.C. and Carvalho, M.E.A. 2014. Effect of bio-stimulant application on production and flavonoid content of marigold (Calendula officinalis L.). Rev. Ceres, Vicosa, 61(6), 983-988.

Mancouso, S., Azzarelto, E., Mugnai, S. and Briand, X. 2006. Marine bioactive substances (IPA extract) improve foliar ion uptake and water tolerance in potted Vitisvinifera plants. Advances in Horticultural Science 20, 156-161.

Mohy EI-Din, S.M. 2015. Utilization of seaweed extracts as bio-fertilizers to stimulate the growth of wheat seedlings. Egyptian J. Exp. Biol. 11(1), 31-39.

Nofal, F.H., El-Segai, M.U. and Seleem, E.A. 2015. Response of Calendula officinalis $\mathrm{L}$. plants to growth stimulants under salinity stress. American-Eurasian J. Agric. \& Environ. Sci., 15(9), 1767-1778.

Norrie, J. and Keathley, J. 2006. Benefit of Ascophyllumnodosummarin plant extract application to Thompson seedless grape production. Acta Hort. 727, 243-247.
Ordog, V., Stirk, W.A., VanStaden, J., Novak, O. and Strand, M. 2004. Endogenous cytokinins in the three genera of microalgae from the chlorophyte. J. Physiol., 40, 88-95.

Renuka, B.N., Christ, R.M. and Kala, T.C. 2011. Seaweed liquid fertilizer as an alternative source of chemical fertilizer in improving the yield of Vigna radiate L. Plant Archives, 11(2), 895-898.

Sarhan, T.Z. 2011. Effect of humic acid and seaweed extracts on growth and yield of potato plants (Solanumtubersum L.). Mesopotamia J. Agric, 39(2), 19-25.

Shaaban, M.M. 2011. Green microalgae water extract as foliar feeding to wheat plants. Pakistan J. Biol. Sci., 4, 628-632.

Snedecor, G.W. and Cochran, W.G. 1990. Statistical Methods.11th. Ed. lowa State College Press. Ames, lowa, U.S.A. pp. 369-373.

Sridhar, S. and Rengasamy, R. 2011. Effect of seaweed liquid fertilizer (slf) on the germination and growth of seedling of some agriculture crops. International J. of Recent Scientific Research, 12, 297-291.

Tarraf. S.A., Talaat, I.M., El-Sayed, A.B. and Balbaa, L.K. 2015. Influence of foliar application of algae extract and amino acids mixture on fenugreek plants in sandy and clay soils. Nusantara Bioscience. 7, 33-37.

Van Staden, J., Upfold, S.J. and Drewes, F.E. 1994. Effect of seaweed concentrate on growth and development of the marigold Tagetespatula J. of Applied Phycology, 6, 427-428.

Venkata, R.P., Raddyand, A.S. and Kotaswara, R.Y. 2015. Effect of seaweed liquid fertilizers on productivity of Vignaradiate L. International J. Res. Chem. Environm., 5(4), 91-94.

Waller, R.A. and Duncan, D.B. 1969. A Bayes rule for the symmetric multiple comparisons problem. J. Am. Stat. Assoc. 46, 1484-1503. 